\title{
Clinical applications of gamma delta T cells with multivalent immunity
}

\author{
Drew C. Deniger ${ }^{1}$, Judy S. Moyes ${ }^{2}$ and Laurence J. N. Cooper ${ }^{2,3}$ * \\ 1 Surgery Branch, National Cancer Institute, Bethesda, MD, USA \\ ${ }^{2}$ Division of Pediatrics, University of Texas MD Anderson Cancer Center, Houston, TX, USA \\ ${ }^{3}$ The University of Texas Graduate School of Biomedical Sciences, UT MD Anderson Cancer Center, Houston, TX, USA
}

\section{Edited by:}

Julie Dechanet-Merville, Centre

National de la Recherche Scientifique (CNRS), France

\section{Reviewed by:}

Sid P. Kerkar, National Institutes of Health, USA

Mary Poupot, Institut National de la

Santé et de la Recherche Médicale,

France

\section{*Correspondence}

Laurence J. N. Cooper, Unit 907, Division of Pediatrics, University of Texas MD Anderson Cancer Center 1515 Holcombe Blvd., Houston, TX 77030, USA

e-mail: ljncooper@mdanderson.org $\gamma \delta T$ cells hold promise for adoptive immunotherapy because of their reactivity to bacteria, viruses, and tumors. However, these cells represent a small fraction (1-5\%) of the peripheral T-cell pool and require activation and propagation to achieve clinical benefit. Aminobisphosphonates specifically expand the $V \gamma 9 \mathrm{~V} \delta 2$ subset of $\gamma \delta T$ cells and have been used in clinical trials of cancer where objective responses were detected. The V $\gamma 9 \mathrm{~V} \delta 2 \mathrm{~T}$ cell receptor (TCR) heterodimer binds multiple ligands and results in a multivalent attack by a monoclonal T cell population. Alternatively, populations of $\gamma \delta$ T cells with oligoclonal or polyclonal TCR repertoire could be infused for broad-range specificity. However, this goal has been restricted by a lack of applicable expansion protocols for non- $V \gamma 9 \mathrm{~V} \delta 2$ cells. Recent advances using immobilized antigens, agonistic monoclonal antibodies (mAbs), tumor-derived artificial antigen presenting cells (aAPC), or combinations of activating mAbs and aAPC have been successful in expanding gamma delta T cells with oligoclonal or polyclonal TCR repertoires. Immobilized major histocompatibility complex Class-I chain-related A was a stimulus for $\gamma \delta$ T cells expressing TCR $\delta 1$ isotypes, and plate-bound activating antibodies have expanded V $\delta 1$ and $V \delta 2$ cells ex vivo. Clinically sufficient quantities of TCR $\delta 1$, TCR $\delta 2$, and TCR $\delta 1^{\text {negTCR } \delta 2^{\text {neg }}}$ have been produced following co-culture on aAPC, and these subsets displayed differences in memory phenotype and reactivity to tumors in vitro and in vivo. Gamma delta T cells are also amenable to genetic modification as evidenced by introduction of $\alpha \beta$ TCRs, chimeric antigen receptors, and drug-resistance genes. This represents a promising future for the clinical application of oligoclonal or polyclonal $\gamma \delta \mathrm{T}$ cells in autologous and allogeneic settings that builds on current trials testing the safety and efficacy of $\mathrm{V} \gamma \mathrm{V} \vee \delta 2 \mathrm{~T}$ cells.

\section{Keywords: cancer, immunotherapy, $\gamma \delta \mathrm{T}$ cells, adoptive T-cell therapy, T-cell receptor, allogeneic transplantation,} chimeric antigen receptors, artificial APC

\section{INTRODUCTION}

$\gamma \delta \mathrm{T}$ cells possess a combination of innate and adaptive immune cell qualities rendering them attractive for immunotherapy (1-3). They can produce inflammatory cytokines, directly lyse infected or malignant cells, and establish a memory response to attack pathogens upon re-exposure. $\gamma \delta \mathrm{T}$ cells are defined by expression of $\gamma$ and $\delta$ heterodimer of T cell receptor (TCR) chains (TCR $\gamma / \mathrm{TCR} \delta)$ that directs intracellular signaling through associated CD3 complexes (4). The $\gamma \delta$ T-cell lineage ( $1-5 \%$ of circulating $\mathrm{T}$ cells) can be contrasted to the more prevalent $\alpha \beta \mathrm{T}$ cell lineage $(\sim 90 \%)$ in peripheral blood, which expresses TCR $\alpha / \mathrm{TCR} \beta$

Abbreviations: 2M3B1PP, 2-methyl-3-butenyl-1-pyrophosphate; AML, acute myeloid leukemia; BrHPP, bromohydrin pyrophosphate; CLL, chronic lymphocytic leukemia; CRC, colorectal cancer; EOC, epithelial ovarian cancer; FCL, follicle center lymphoma; GI-cancer, cancers from the gastrointestinal tract; HIV, human immunodeficiency virus; HRPC, hormone-refractory prostate cancer; IC, immunocytoma; $\mathrm{MM}$, multiple myeloma; MZL, mantle zone lymphoma; N/D, not determined; NHL, T-cell non-Hodgkin lymphoma; NSCLC, non-small-cell lung cancer; RCC, renal cell carcinoma; TBI, total body irradiation; T-SPL, secondary plasma cell leukemia; Zol, zoledronic acid. heterodimers and also signals through associated $\mathrm{CD} 3$ complexes $(5,6)$. CD4 and CD8 co-receptors on $\alpha \beta \mathrm{T}$ cells assist binding of TCR $\alpha \beta$ chains to the major histocompatibility complex (MHC) presenting processed peptides (7-9). In contrast, TCR $\gamma \delta$ directly binds to an antigen's superstructure independent of the $\mathrm{MHC} /$ peptide complexes and, as a result, CD4 and CD8 are uncommon on $\gamma \delta \mathrm{T}$ cells $(10,11)$. Given that antigen recognition is achieved outside of MHC/peptide-restriction, $\gamma \delta \mathrm{T}$ cells have predictable immune effector functions mediated through their TCR and have potential use as universal ("off-the-shelf") allogeneic T-cell therapies (12).

Functional responses by $\gamma \delta \mathrm{T}$ cells can be stratified by the variable $(\mathrm{V})$ region of the TCR $\delta$ chain. In humans, the TCR $\delta$ locus (TRD) lies within the TCR $\alpha$ locus (TRA). Three unique $V \delta$ alleles, TRDV1, TRDV2, and TRDV3, code for TCR $\delta 1$, TCR $\delta 2$, and TCR $\delta 3$, respectively. Additionally, shared V $\delta$ and $\mathrm{V} \alpha$ variable regions exist in TRDV4/TRAV14, TRDV5/TRAV29, TRDV6/TRAV23, TRDV7/TRAV36, and TRDV8/TRAV38-2 loci. Recombination of these shared $\mathrm{V}$ alleles with a TRA junction region (TRAJ) results in TCR $\alpha 14, \mathrm{TCR} \alpha 29, \mathrm{TCR} \alpha 23$, TCR $\alpha 36$, 
and TCR $\alpha 38-2$, respectively, but recombination of these shared V alleles with TRD junction (TRDJ) and diversity (TRDD) regions results in TCR $\delta 4, \mathrm{TCR} \delta 5, \mathrm{TCR} \delta 6, \mathrm{TCR} \delta 7$, and TCR $\delta 8$, respectively (13). Expression of TCR $\gamma \delta$ heterodimers on the T-cell surface in the thymus inhibits recombination of TCR $\beta$-chain locus during the $\mathrm{CD} 4^{\text {neg }} \mathrm{CD} 8^{\text {neg }}$ stage thereby committing the T cell to the $\gamma \delta$ T-cell lineage (14). This double negative status is typically maintained upon exit from the thymus, most likely because co-receptors are dispensable for functional TCR $\gamma \delta$ binding to antigens (15). However, the thymus is not required to complete all $\gamma \delta$ T-cell development, as many $\gamma \delta \mathrm{T}$ cells directly take up residence in peripheral tissues following exit from the bone marrow and exhibit immediate effector functions against pathogens (16). Thymusindependent "resident" $\gamma \delta \mathrm{T}$ cells can be found in the mucosa, tongue, vagina, intestine, lung, liver, and skin and can comprise up to $50 \%$ of the T-cell populations in intestinal epithelial lymphocytes $(17,18)$. In contrast, circulating $\gamma \delta \mathrm{T}$ cells can be found in the blood and lymphoid organs, and are dominated by $\gamma \delta \mathrm{T}$ cells preferentially expressing TCR $\delta 2$ isotype (commonly referred to as $\mathrm{V} \delta 2$ cells). Indeed, $\gamma \delta \mathrm{T}$ cells expressing the TCR $\delta 1$ isotype (commonly referred to as $\mathrm{V} \delta 1$ cells) are frequently found within tissues $(19,20)$. V $\delta 2$ cells have preferred pairing with TCR $\gamma 9(\mathrm{~V} \gamma 9 \mathrm{~V} \delta 2$ cells), but broad $\gamma$-chain pairing is observed in $\mathrm{V} \delta 1$ cells and $\mathrm{V} \delta 1^{\text {neg }} \mathrm{V} \delta 2^{\text {neg }}$ cells, a generic grouping of all other non-V $\delta 1 / \mathrm{V} \delta 2 \mathrm{~T}$ cells $(12,19)$. Therefore, $\gamma \delta \mathrm{T}$ cells are distributed across an array of anatomical locations with a range of TCR $\gamma \delta$ variable region expression.

Human TCR $\gamma \delta$ ligands are MHC/peptide complex-independent and are therefore conserved amongst unrelated individuals. Most of the known human ligands are specific for TCR $\delta 1$ or TCR $\delta 2$. TCR $\gamma 1 / \mathrm{TCR} \delta 1$ (alternatively termed V $\gamma 1 \mathrm{~V} \delta 1$ ) heterodimers have specificity for MHC Class-I chain-related A (MICA) (21, 22), a molecule participating in evasion of immune surveillance following viral infection and expressed on tumor cells as it is involved in the cellular stress response (23). MICA is also one of the ligands for NKG2D, which is expressed on $\gamma \delta \mathrm{T}$ cells, $\alpha \beta \mathrm{T}$ cells, and natural killer $(\mathrm{NK})$ cells $(23,24)$. Both $\mathrm{V} \gamma 1 \mathrm{~V} \delta 1$ and $\mathrm{V} \gamma 2 \mathrm{~V} \delta 1$ recognize non-polymorphic $\mathrm{MHC}$ molecule CD1c (25), and $\mathrm{V} \gamma 5 \mathrm{~V} \delta 1$ is a receptor for $\alpha$-galactosylceramide-CD1d complexes commonly described in the activation of natural killer $\mathrm{T}$ (NKT) cells which, like $\gamma \delta \mathrm{T}$ cells, have both innate and adaptive immune functions and recognize conserved ligands amongst unrelated individuals $(26,27) . \gamma \delta \mathrm{T}$ cells can have specificity for virus as cytomegalovirus (CMV)-reactive $\mathrm{V} \gamma 8 \mathrm{~V} \delta 1$ cells have been isolated from umbilical cord blood from infected newborns (28). $\mathrm{V} \delta 1$ cells have also been associated with immunity to human immunodeficiency virus (HIV), but the precise HIV ligands for TCR $\delta 1$ have not been determined (29). Bacterial alkylamines and Listeria monocytogenes are recognized by $\mathrm{V} \delta 2$ cells when paired with $\mathrm{V} \gamma 2$ (30-32). V $\gamma 9 \mathrm{~V} \delta 2$ cells are the most extensively studied sub-group of human $\gamma \delta$ T cells and their ligands include phosphoantigens [isopentenyl pyrophosphate (IPP)], $\mathrm{F}_{1}$-ATPase expressed on the cell surface, apolipoprotein A-I, and Mycobacterium tuberculosis (33-37). Moreover, V $\gamma 9 \mathrm{~V} \delta 2$ cells controlled and prevented lethal Epstein-Barr virus (EBV)-transformed leukemia xenografts in immunocompromised mice (4), and in vitro and in vivo data suggested that $\mathrm{V} \delta 1$ cells are also specific for $\operatorname{EBV}(38,39)$. In contrast to $\mathrm{V} \delta 1$ and $V \delta 2$ cells, very little is known about human $\gamma \delta$ T cells expressing other TCR $\gamma \delta$ alleles except for indirect evidence of V $\delta 3$ cell's immunity against CMV and HIV (40, 41). Given the multivalent nature of $\gamma \delta \mathrm{T}$ cells, harnessing $\gamma \delta \mathrm{T}$ cells populations with polyclonal TCR repertoire is attractive for adoptive immunotherapy.

\section{$\gamma \delta$ T-CELL CLINICAL EXPERIENCE}

Immunotherapy with $\gamma \delta \mathrm{T}$ cells requires their activation and expansion as they comprise only a small percentage of circulating $\mathrm{T}$ cells. Interleukin-2 (IL-2) and activating CD3 antibody (OKT3), commonly used for the propagation of $\alpha \beta$ T cells directly from peripheral blood mononuclear cells (PBMC), do not reliably expand $\gamma \delta \mathrm{T}$ cells without further manipulation and so alternative approaches are needed. Aminobisphosphonates, e.g., Zoledronic Acid (Zol), used in the treatment of bone-related diseases, e.g., osteoporosis, resulted in in vivo propagation of $\gamma \delta$ $\mathrm{T}$ cells, and the use of aminobisphosphonates has been subsequently translated into laboratory practice to grow $\gamma \delta \mathrm{T}$ cells $e x$ vivo (Figure 1A) (42, 43). Aminobisphosphonates inhibit cholesterol synthesis and result in the accumulation of phosphoantigen intermediates in the mevalonate-CoA pathway, including IPP, a ligand for $\mathrm{V} \gamma 9 \mathrm{~V} \delta 2$ (44). However, only the V $\gamma 9 \mathrm{~V} \delta 2 \mathrm{~T}$-cell subset is reactive to cells treated with phosphoantigens $(45,46)$. Synthetic phosphoantigens, e.g., bromohydrin pyrophosphate (BrHPP) (47) and 2-methyl-3-butenyl-1-pyrophosphate (2M3B1PP) (48), can mimic aminobisphosphonates and stimulate $\mathrm{V} \gamma 9 \mathrm{~V} \delta 2 \mathrm{~T}$ cells for proliferation.

These reagents have been transitioned to the clinic for investigational treatments of cancer and HIV (Table 1) (49, 50). Six trials have evaluated the ability of aminobisphosphonates or BrHPP to generate in vivo expansions of $\mathrm{V} \gamma 9 \mathrm{~V} \delta 2 \mathrm{~T}$ cells to fight leukemia/lymphoma (51, 52), melanoma (52), renal cell carcinoma (RCC) $(52,53)$, hormone-refractory prostate cancer (HRPC) (54), breast cancer (55), and HIV (56). These trials established safety of large $\mathrm{V} \gamma 9 \mathrm{~V} \delta 2 \mathrm{~T}$ cell expansions in vivo and generated a total of nine objective responses $(11.3 \% ; N=80)$ but no complete responses (CR) as anti-tumor therapies. Six clinical trials have used either Zol, BrHPP, or 2M3B1PP to expand autologous V $\gamma 9 \mathrm{~V} \delta 2 \mathrm{~T}$ cells ex vivo and these cells were directly infused (three trials with added IL-2 infusion and three without) for treatment of RCC (57-59), non-small cell lung cancer (NSCLC) (60, 61 ), and colorectal cancer (CRC) (62). Direct infusion of $\mathrm{V} \gamma 9 \mathrm{~V} \delta 2$ $\mathrm{T}$ cells was established as a safe regimen and a total of eight objective responses $(11.3 \% ; N=71)$ were detected, including one $\mathrm{CR}$ $(1.4 \% ; N=71)(62)$. Three trials have evaluated the combination of adoptive transfer of ex vivo expanded $\mathrm{V} \gamma 9 \mathrm{~V} \delta 2 \mathrm{~T}$ cells followed by Zol administration to boost their in vivo proliferation. Multiple myeloma (63), RCC (64), and multiple metastatic tumors (melanoma, CRC, gastrointestinal tumors, ovarian cancer, breast cancer, cervical cancer, and bone cancer) (65) were treated with this combination, which was established to be safe, and four objective responses $(13.8 \% ; N=29)$ were observed, two of which were CRs $(6.9 \% ; N=29)$ treating intermediate-stage RCC (64) and breast cancer (65). Thus, adoptive transfer and in vivo expansions of $\mathrm{V} \gamma 9 \mathrm{~V} \delta 2 \mathrm{~T}$ cells are safe therapeutic modalities and can result in objective clinical responses in the treatment of cancer. 

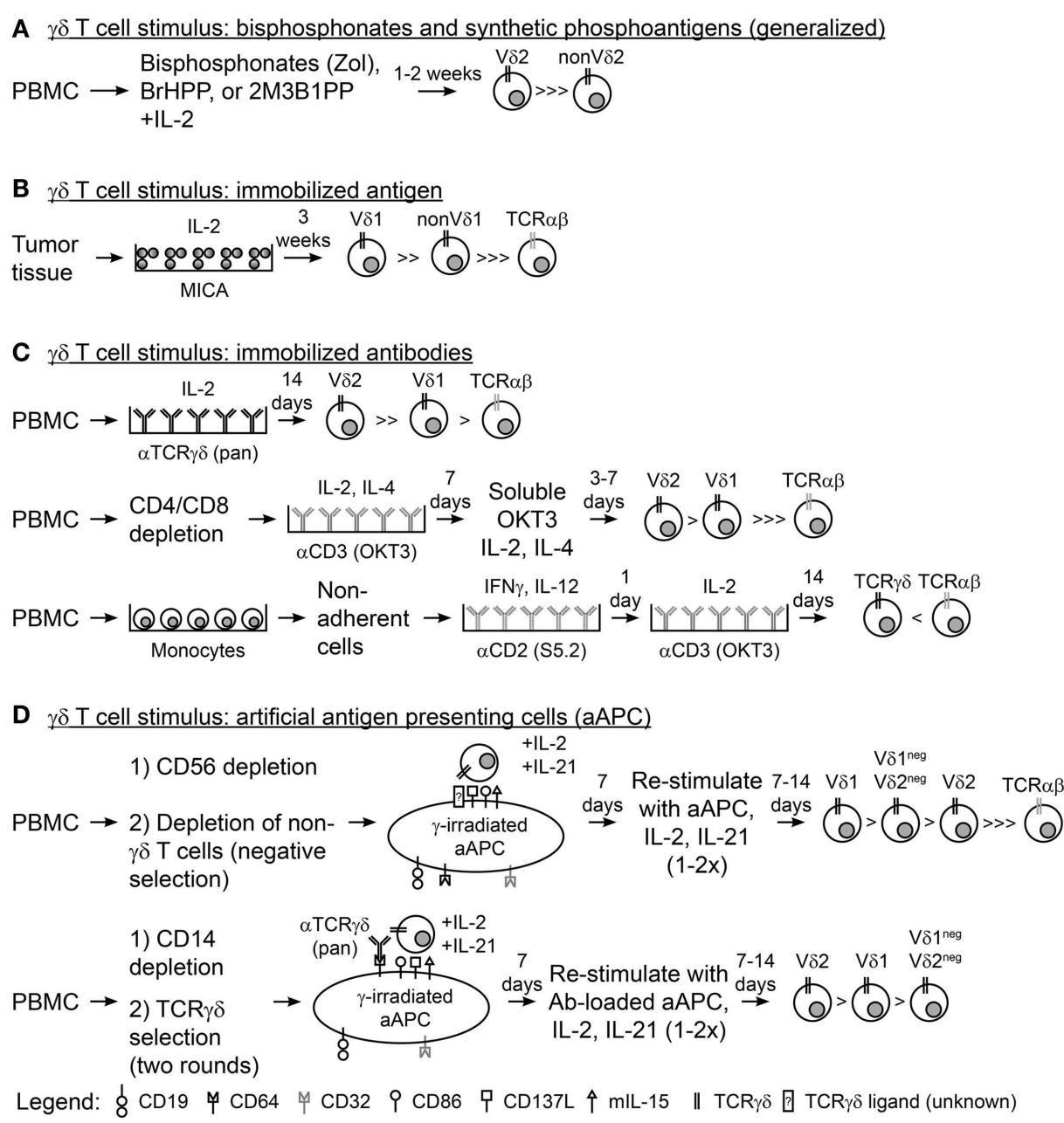

\section{FIGURE 1 | Methodologies for expanding $\gamma \delta$ T cells ex vivo.}

(A) A generalized schematic for the use of aminobisphosphonates (Zol, zoledronic acid) or synthetic phosphoantigens (BrHPP, bromohydrin pyrophosphate; 2M3B1PP, 2-methyl-3-butenyl-1-pyrophosphate) and interleukin-2 (IL-2) to expand $\gamma \delta$ T cells from peripheral blood mononuclear cells (PBMC). (B) Plate-bound MHC class-I chain-related (MICA) and IL-2 were used to expand $\gamma \delta$ T cells from colon and ovarian tumor tissues. (C) Immobilized antibodies (Ab) were used to expand $\gamma \delta T$ cells from PBMC in three scenarios: (top) PBMC directly stimulated with anti-pan-TCR $\gamma \delta$ Ab and IL-2, (middle) PBMC depleted of CD4 and CD8T cells followed by two rounds of stimulus with anti-CD3 Ab (OKT3), IL-2, and IL-4, and (bottom) PBMC were depleted of non-adherent cells, stimulated with anti-CD2 Ab (S5.2), interferon- $\gamma(\mathrm{IFN} \gamma)$, and IL-12, then stimulated with OKT3 and IL-2. (D) Schematic for the use of artificial antigen presenting cells ( $\mathrm{AAPC}$ ) to expand $\gamma \delta \mathrm{T}$ cells from PBMC in two scenarios: (top) PBMC was depleted of $\mathrm{CD}^{2} 6^{+} \mathrm{NK}$ cells then of other non- $\gamma \delta$ T cells (TCR $\gamma / \delta+$ magnetic bead kit) so that $\gamma \delta$ T cell were isolated by "negative selection" and co-cultured recursively with aAPC, IL-2, and IL-21 for 2-3 rounds of stimulation; (bottom) PBMC was depleted of $\mathrm{CD} 14^{+}$monocytes and "positively selected" with TCR $\gamma \delta$ magnetic beads then co-cultured recursively with anti-TCR $\gamma \delta$ Ab-loaded aAPC, IL-2, and IL-21 for 2-3 rounds of stimulation.
Allogeneic $\gamma \delta \mathrm{T}$ cells have also been infused but were part of heterogeneous cell populations (Table 1). Patients with acute myelogenous leukemia (AML) and acute lymphoblastic leukemia (ALL) were treated with $\alpha \beta \mathrm{T}$ cell-depleted hematopoietic stem cell transplant (HSCT), which resulted in 100 objective responses (65\%; $N=153)$ with 36 durable CRs $(24 \% ; N=153)(66-69)$. These complete remissions could be directly correlated to the elevated persistence of donor-derived V $\delta 1$ cells in the peripheral blood of the patients, suggesting that these cells were involved in long-term clearance of leukemia. Increases in peripheral V $\delta 1$ cells have also been correlated with CMV re-activation in patients with leukemia following allogeneic $\operatorname{HSCT}(40,70)$. Most recently, haploidentical PBMC were depleted of $\mathrm{CD}^{+}$and $\mathrm{CD}^{+}$cells using magnetic beads and were administered to patients with refractory hematological malignancies followed by Zol and IL2 infusions (71). Three of the four patients treated experienced short-lived CRs (2, 5, and 8 months) and the other patient died of infection 6 weeks after treatment. Expansion of $\gamma \delta \mathrm{T}$ cells was observed the week after treatment suggesting that they may have directed the anti-tumor response. Currently, clinical trials of direct infusion of activated, homogenous populations of $\mathrm{V} \delta 1$ cells, or other non- $\mathrm{V} \gamma 9 \mathrm{~V} \delta 2$ cells have yet to be undertaken but hold promise as future avenues of medical intervention. 
Table 1 | Clinical responses from $\gamma \delta$ T cells.

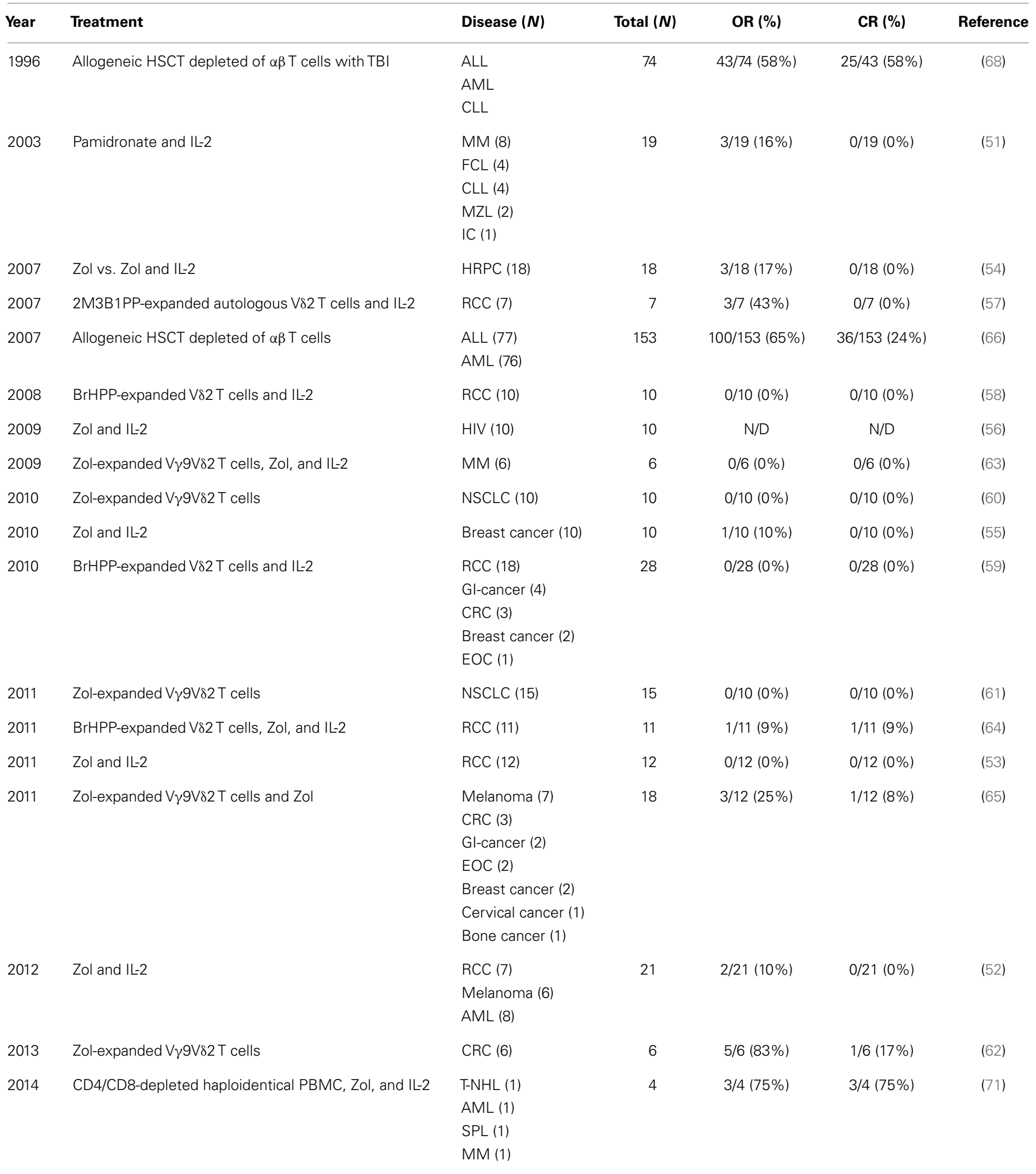

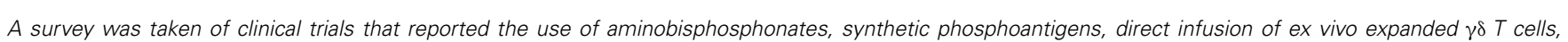

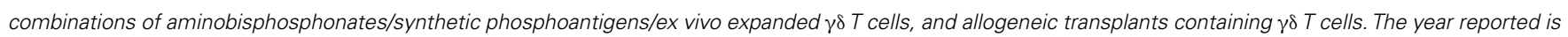

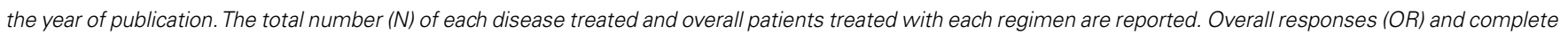

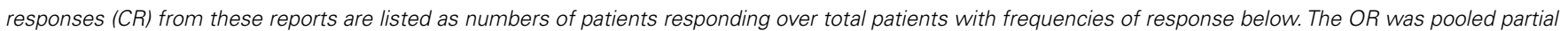

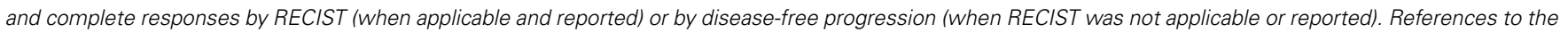
clinical trials are included in the far right column. 


\section{EX VIVO PROPAGATION OF NON-V $\gamma 9 \mathrm{~V} \delta 2 \gamma \delta$ T CELLS}

Populations of $\gamma \delta \mathrm{T}$ cells outside of the $\mathrm{V} \gamma 9 \mathrm{~V} \delta 2$ subset have been grown with immobilized TCR $\gamma \delta$ agonists. Plate-bound recombinant MICA and IL-2 were used to sustain the proliferation of $\gamma \delta$ T-cell cultures ex vivo from epithelial ovarian cancer and CRC tumor infiltrating lymphocytes (TILs) and resulted in high frequencies of V $\delta 1$ cells (Figure 1B) (72). In addition, plate-bound pan-TCR $\gamma \delta$-specific antibody and IL-2 led to proliferation of both $\mathrm{V} \delta 2$ and $\mathrm{V} \delta 1$ cells $(\mathrm{V} \delta 2>>\mathrm{V} \delta 1)$ from peripheral blood derived from both healthy donors and patients with lung cancer or lymphoma (Figure 1C, top) $(73,74)$. Similarly, OKT3 has been used in combination with IL-2 and IL-4 to stimulate CD4/CD8-depleted $\mathrm{T}$ cells from healthy peripheral blood, which resulted in expansion of $\mathrm{V} \delta 2$ and $\mathrm{V} \delta 1$ cells $(\mathrm{V} \delta 2>\mathrm{V} \delta 1)$, albeit with reduced cell numbers compared to the TCR $\gamma \delta$ monoclonal antibody (mAb)stimulated cells (Figure 1C, middle) (75). A more complex cocktail of cytokines [IL-2, IL-12, and Interferon- $\gamma($ IFN $\gamma)$ ] has also been used with OKT3 and CD2-specific antibodies to expand $\gamma \delta \mathrm{T}$ cells, but the $\mathrm{V} \delta$ repertoires were not reported (Figure 1C, bottom) (76). Transition of these immobilized antigens and antibodies into clinical manufacture will streamline the application of these expansion strategies for $\gamma \delta \mathrm{T}$ cells and could be the source of clinical trials with non- $\mathrm{V} \gamma 9 \mathrm{~V} \delta 2$ cells.

Highly polyclonal $\gamma \delta \mathrm{T}$ cells have been generated through coculture of patient or healthy donor $\gamma \delta \mathrm{T}$ cells with irradiated artificial antigen presenting cells (aAPC), IL-2, and IL-21 (77-80). The aAPC (clone\#4) are derived from the chronic myelogenous leukemia (CML) cell line K562 following genetic modification with T-cell co-stimulatory molecules (CD86 and CD137L), Fc receptors for antibody loading (introduced CD64 and endogenous CD32), antigens (CD19), and cytokines (a membrane-bound IL15), and have been produced as a master cell bank (MCB) (81). This MCB is currently used in the production of $\alpha \beta$ T cells for cancer treatments in clinical trials at MD Anderson (NCT01653717, NCT01619761, NCT00968760, and NCT01497184) (79, 82, 83). $\gamma$-irradiation of aAPC prior to co-culture with T cells subjects the aAPC to death (typically at or within 3 days) thereby reducing the risk for unintended transfer of this tumor cell line into recipients (83). Deniger et al. demonstrated that circulating $\gamma \delta$ $\mathrm{T}$ cells, containing a polyclonal TCR $\gamma \delta$ repertoire, could be isolated from healthy donor venipuncture or umbilical cord blood by "unlabeled/negative" magnetic bead selection and recursively stimulated with irradiated aAPC, IL-2, and IL-21 (Figure 1D, top). The aAPC-expanded $\gamma \delta \mathrm{T}$ cells proliferated to numbers sufficient for clinical use while maintaining the expression of most $T R D V$ and TRGV alleles and demonstrating TCR $\delta$ surface expression of $\mathrm{V} \delta 1>\mathrm{V} \delta 1^{\text {neg }} \mathrm{V} \delta 2^{\text {neg }}>\mathrm{V} \delta 2(77)$. These polyclonal $\gamma \delta \mathrm{T}$-cell cultures displayed broad tumor reactivity as they were able to lyse leukemia, ovarian cancer, pancreatic cancer, and colon cancer cells. Separation of the polyclonal cultures by TCR $\delta$ surface expression showed that each T-cell subset had anti-tumor reactivity and that a polyclonal $\gamma \delta \mathrm{T}$-cell population led to the superior survival of mice with established ovarian cancer xenografts. Propagation of $\mathrm{V} \delta 1^{\text {neg }} \mathrm{V} \delta 2^{\text {neg }}$ cells had not been previously achieved and this was the first evidence of the functional activity of this $\gamma \delta$ T-cell sub-population. In a similar study, Fisher et al. isolated polyclonal $\gamma \delta \mathrm{T}$ cells from PBMC of healthy donors or patients with neuroblastoma by first depleting monocytes followed by "positive/labeled" selection with anti-TCR $\gamma \delta$-hapten antibody and anti-hapten microbeads (Figure 1D, bottom) (79). This study made use of the Fc receptors on the aAPC surface to load anti$\mathrm{TCR} \gamma \delta$ antibody where isolated $\gamma \delta \mathrm{T}$ cells were co-cultured with the antibody-loaded aAPC. These expanded $\gamma \delta \mathrm{T}$ cells expressed multiple TRDV and TRGV alleles with surface TCR $\delta$ expression of $\mathrm{V} \delta 2>\mathrm{V} \delta 1>\mathrm{V} \delta 1^{\text {neg }} \mathrm{V} \delta 2^{\text {neg }}$. Using this mode of expansion, $\mathrm{V} \delta 1$ and $\mathrm{V} \delta 2$ were mediators of antibody-independent (AIC) and antibody-dependent cellular cytotoxicity (ADCC), respectively, to neuroblastoma tumor cells (as predicted by whether or not they expressed Fc receptor CD16). aAPC-expanded polyclonal $\gamma \delta \mathrm{T}$ cells could be used for anti-tumor therapies because aAPC are currently available as a clinical reagent. However, human application of aAPC/mAb-expanded $\gamma \delta \mathrm{T}$ cells could depend on interest in the use of the current MCB of aAPC, generation of new $\mathrm{MCB}$ of aAPC at institutions where there are currently none, and production of $\gamma \delta \mathrm{T}$ cell agonistic antibodies in good manufacturing practice (GMP) conditions. Clinical testing of these cells could potentially lead to more widespread acceptance and use of $\gamma \delta \mathrm{T}$ cells as adoptive cellular therapies.

Given that the aAPC can sustain the proliferation of non$\mathrm{V} \gamma 9 \mathrm{~V} \delta 2$ cells to large quantities, there is opportunity for clinical translation, laboratory testing of subsets to elucidate their functions, and correlative studies. A limiting factor in studying $\gamma \delta \mathrm{T}$ cells has been the lack of TCR $\delta$ and TCR $\gamma$ isotype-specific antibodies outside of specificity for TCR $\delta 1$, TCR $\delta 2$, TCR $\gamma 9$, and TCR $\delta 3$ (where commercially available). Mice can now be immunized to generate $\mathrm{mAb}$ specific for desired TCR $\gamma \delta$ isotypes where commercial and academic use of these detection antibodies can have tangible outcomes, including diagnostic and/or prognostic profiling of $\gamma \delta \mathrm{T}$ cells resident within tumors. $\gamma \delta \mathrm{T}$-cell clones could be generated through co-culture of single $\gamma \delta \mathrm{T}$ cells with aAPC, and this can facilitate studies to determine $\mathrm{V} \delta / \mathrm{V} \gamma$ pairing, corresponding TCR $\gamma \delta$ ligands, and pathogenic reactivity. The ligands on the K562-derived aAPC that TCR $\gamma \delta$ binds are not currently known. Likely candidates include IPP and MICA/B for TCR $\delta 2$ and TCR $\delta 1$, respectively $(22,35)$. Elucidation of these interactions could assist attempts to tailor the design of the aAPC for total $\gamma \delta$ T-cell expansion, propagation of a particular $\gamma \delta$ T-cell lineage, or polarization toward a certain $\gamma \delta$ T-cell phenotype (84). As an example, $\mathrm{CD} 27^{\text {neg }}$ and $\mathrm{CD} 27^{+} \gamma \delta \mathrm{T}$ cells are associated with IL17 and IFN $\gamma$ production, respectively (85-87), leading to the conclusion that expression of CD70, the CD27 ligand, on aAPC could potentially polarize these $\mathrm{T}$ cells toward a desired cytokine output. Thus, aAPC could be an excellent source for the study of fundamental $\gamma \delta$ T-cell immunobiology and could yield answers not currently accessible because of limited starting cell numbers and ineffective polyclonal expansion protocols.

\section{GENETIC MODIFICATION OF $\gamma \delta$ T CELLS FOR THERAPEUTIC USE}

$\gamma \delta \mathrm{T}$ cells are also amenable to genetic modification allowing for the introduction of genes to improve their therapeutic function. For instance, re-directed specificity of $\mathrm{T}$ cells can also be accomplished through the introduction of recombinant TCRs with defined antigen specificity. The conventional thought is 
that transfer of TCR $\alpha / \operatorname{TCR} \beta$ genes into $\gamma \delta \mathrm{T}$ cells or transfer of TCR $\gamma / \mathrm{TCR} \delta$ genes into $\alpha \beta$ T cells would not cause mispairing with the TCR $\alpha / \operatorname{TCR} \beta$ and TCR $\gamma / \operatorname{TCR} \delta$ heterodimers, thereby mitigating the risk of generating inappropriate pairings such as TCR $\alpha /$ TCR $\delta$, TCR $\alpha / \operatorname{TCR} \gamma, \operatorname{TCR} \beta / \mathrm{TCR} \gamma$, or TCR $\beta / \mathrm{TCR} \delta$ heterodimers with unknown specificity (88). This mis-pairing hypothesis was modeled in mice with the ovalbumin-specific $\alpha \beta$ TCR OT-I, which resulted in re-directed specificity of murine $\gamma \delta \mathrm{T}$ cells toward ovalbumin peptide, but whether or not the TCRs were actually mis-paired was not reported (89). V $\gamma 2 \mathrm{~V} \delta 2$ cells have been expanded with 2M3B1PP and infected with $\gamma$ retrovirus to transduce $\mathrm{TCR} \alpha \beta$ chains with specificity toward MAGE-A4 peptide, but co-transduction with CD8 was required in order to transfer significant MHC Class-I-restricted recognition of MAGE-A4 peptide-pulsed tumor cells (90, 91). Similar studies have transferred $\alpha \beta$ TCRs specific for CMV pp65 peptide or minor histocompatibility antigens into $\gamma \delta \mathrm{T}$ cells rendering them reactive to antigen-appropriate tumor cells (92). In contrast to the above reports of introducing $\alpha \beta$ TCRs into $\gamma \delta$ T cells, the $\mathrm{V} \gamma 9 \mathrm{~V} \delta 2$ TCR has been transferred into $\alpha \beta$ T cells and rendered both $\mathrm{CD}^{+}{ }^{+}$and $\mathrm{CD}^{+} \mathrm{T}$ cells reactive to multiple tumor cell lines (93). Chemotherapy (temozolomide)-resistant $\gamma \delta$ T cells have been generated by lentiviral transduction of (6)-alkylguanine DNA alkyltransferase into V $\gamma 9 \mathrm{~V} \delta 2$ cells expanded on Zol (94). Chimeric antigen receptors (CARs) can be introduced into $\mathrm{T}$ cells and re-direct the $\mathrm{T}$ cell toward a specific antigen. CARs are formed by fusing a single chain antibody to one or more T-cell intracellular signaling domains, e.g., CD3 $\zeta, \mathrm{CD} 28$, and/or CD137 (95). The antibody confers specificity through its variable regions toward a particular antigen, e.g., CD19, GD 2, HER2, etc., and CAR binding to the antigen transmits intracellular T-cell signals for antigen-dependent proliferation, cytokine production, and cytolysis $(96,97)$. Following expansion on Zol, V $\gamma 9 \mathrm{~V} \delta 2$ cells were efficiently transduced to express CD19- and $\mathrm{GD}_{2}$-specific CARs with $\gamma$-retroviral vectors and displayed re-directed specificity toward CD19 ${ }^{+}$and $\mathrm{GD}_{2}{ }^{+}$tumor targets, respectively (98). Zol and $\gamma$-retroviruses engineered to transduce CD19- and $\mathrm{GD}_{2}$ specific CARs are available for human application, but have not been combined in a clinical trial to date. Thus, subsets of $\gamma \delta \mathrm{T}$ cells are amenable to viral gene transfer to improve their therapeutic impact.

In contrast to $\gamma$-retroviruses and lentiviruses, which require cell division for efficient transduction, non-viral Sleeping Beauty (SB) transposition transfers genes into quiescent T cells and allows manipulation of cells that are difficult to culture ex vivo (99-102). SB transposase enzyme was originally derived from fish that were undergoing active transposition in their evolutionary maturation and was adapted for human application (103). In short, a DNA transposon with flanking inverted repeats and direct repeats is ligated into the human genome at TA dinucleotide repeats by the SB transposase enzyme (104). TA dinucleotide repeats are widely distributed in the human genome, yielding potential for random integration into the genome, and have been shown to be safe in regards to transgene insertion in pre-clinical studies $(99,101,105)$. This is of particular importance in gene therapy as inappropriate integration at gene start sites or promoters, within exons, or even distal to genes within enhancers or repressors may cause cellular transformation. Lentiviruses and $\gamma$-retroviruses have higher efficiency in transgene delivery than SB, but these vectors are known to integrate near genes or within genes (97). Application of SB to human clinical-grade $\mathrm{T}$ cells has been reduced to practice as a two DNA plasmid system, where one plasmid contains the SB transposon with the transgene of interest, e.g., CAR, and the other plasmid encodes a hyperactive SB transposase (106). Electro-transfer of the DNA plasmids by nucleofection into circulating (quiescent) PBMC results in transient expression of SB transposase that then ligates the transposon into the genome using a "cut-and-paste" mechanism. As soon as the SB transposase mRNA is degraded translation of SB transposase protein is halted, thereby negating additional transposition events. T cells with stable CAR expression can be encouraged through the co-culture of T cells on irradiated aAPC that express antigen for the CAR (83). This process, originally developed for $\alpha \beta \mathrm{T}$ cells, has been adapted for expression of CAR in $\gamma \delta \mathrm{T}$ cells (78). Resting PBMCs were electroporated with CD19-specific CAR transposon and SB11 transposase plasmids and sorted the following day to deplete non- $\gamma \delta \mathrm{T}$ cells with magnetic beads from the transfected mixture. Isolated $\gamma \delta \mathrm{T}$ cells were recursively stimulated with $\mathrm{CD} 19^{+}$aAPC along with IL-2 and IL-21, which resulted in the outgrowth of $\mathrm{CAR}^{+} \gamma \delta$ $\mathrm{T}$ cells with a highly polyclonal TCR $\gamma \delta$ repertoire. Endogenous leukemia reactivity by the aAPC-expanded $\gamma \delta$ T cells was improved through expression of CD19-specific CAR rendering these T cells bi-specific through CAR and TCR $\gamma \delta$. SB transposon and transposase are available as clinical reagents; therefore, clinical trials can test the safety and efficacy of bi-specific $\mathrm{CAR}^{+} \gamma \delta \mathrm{T}$ cells.

\section{CONCLUDING REMARKS}

Given that $\gamma \delta$ T cells are unlikely to cause graft-versus-host disease (GVHD) because their TCR ligands (IPP, MICA, etc.) are not MHC-restricted, $\gamma \delta \mathrm{T}$ cells (with or without genetic modification) could be generated from healthy donors in a third party manufacturing facility and given in the allogeneic setting as an "off-the-shelf" therapeutic. Additionally, a "universal" bank of polyclonal $\gamma \delta$ T cells could be established that was known to have high anti-tumor immunity or contain a particular set frequency of $\mathrm{V} \delta 1, \mathrm{~V} \delta 2$, and $\mathrm{V} \delta 1^{\text {neg }} \mathrm{V} \delta 2^{\text {neg }}$ populations to achieve superior efficacy (66). This could have specialized application in cases where $\mathrm{T}$ cells were difficult to manufacture, e.g., high tumor burden in blood or after extensive systemic (lymphodepleting) chemotherapy. Polyclonal $\gamma \delta$ T cells could also be used as front-line therapy before addition of HSCT, CAR ${ }^{+}$T cells, TILs, etc. in order to prime the tumor microenvironment for other adaptive immune cells with broader tumor specificity or to reveal neo-tumor antigens, including somatic non-synonymous mutations expressed only in the tumor (107-109). If immunity is restored in the recipients then the 3rd party $\gamma \delta$ T-cell graft may be rejected, but there may still be a therapeutic window before this occurs. Both pro-tumor and anti-tumor effects of $\gamma \delta$ T cells infiltrating the tumor microenvironment have been described $(110,111)$, and whether or not these cells could be useful for therapy could be delineated following expansion of $\gamma \delta$ T cells from solid tumors on aAPC, which have been shown to expand TIL ( $\alpha \beta$ T cells) from metastatic melanoma (112). Tumor lysis by $\gamma \delta \mathrm{T}$ cells could lead to other resident cell types, e.g., NK cells, macrophages, $\alpha \beta$ T cells, etc., to have renewed 
reactivity to the malignancy (113). Indeed, B-ALL cell lines coated with $\mathrm{mAb}$ were lysed by $\mathrm{CD} 16^{+} \mathrm{V} \gamma 9 \mathrm{~V} \delta 2$ cells via ADCC, and subsequently the $\mathrm{V} \gamma 9 \mathrm{~V} \delta 2$ had antigen presenting cell function to generate antigen-specific $\mathrm{CD}^{+} \alpha \beta$ T cell responses to known $\mathrm{B}$ ALL peptides, e.g., PAX5 $(114,115)$. Unknown is whether $\gamma \delta \mathrm{T}$ cells will be subjected to inhibition by regulatory $\mathrm{T}$ cells or other immunosuppressive forces. Some $\gamma \delta \mathrm{T}$ cells have been reported to have immunosuppressive function, and it would be of interest to identify these cells and eliminate them from the adoptive Tcell product prior to infusion (116). In summary, administration of graded doses of autologous and allogeneic, even 3rd party, $\gamma \delta$ $\mathrm{T}$ cells in humans have tested and will continue to evaluate the ability of these lymphocytes to home and recycle effector function in the tumor microenvironment. Given the development of aminobisphosphonates, synthetic phosphoantigens, immobilized antigens, antibodies, and designer clinical-grade aAPC, it now appears practical to sculpt and expand $\gamma \delta \mathrm{T}$ cells to achieve a therapeutic effect.

\section{AUTHOR CONTRIBUTIONS}

Drew C. Deniger, Judy S. Moyes, and Laurence J. N. Cooper wrote the manuscript.

\section{ACKNOWLEDGMENTS}

Funding for this work was provided by Cancer Center Core Grant (CA16672); RO1 (CA124782, CA120956, CA141303; CA141303); P01 (CA148600); SPORE (CA83639); Albert J. Ward Foundation; Alex Lemonade Stand Foundation; American Legion Auxiliary, Burroughs Wellcome Fund; Cancer Answers; Cancer Prevention and Research Institute of Texas; Charles B. Goddard Foundation of Texas; CLL Global Research Foundation; DARPA (Defense Sciences Office); Department of Defense; Estate of Noelan L. Bibler; Gillson Longenbaugh Foundation; Harry T. Mangurian, Jr., Fund for Leukemia Immunotherapy; Khalifa Bin Zayed Al Nahyan Foundation; Leukemia and Lymphoma Society; Lymphoma Research Foundation; Miller Foundation; Moon Shot program at MDACC, Mr. Herb Simons; Mr. and Mrs. Joe H. Scales; Mr. Thomas Scott; National Foundation for Cancer Research; Pediatric Cancer Research Foundation; Sheikh Khalifa Bin Zayed Al Nahyan Institute for Personalized Cancer Therapy; R. W. Butcher Foundation, University of Texas MD Anderson Cancer Center Sister Institution Network Fund and Moon Shot Fund; William Lawrence and Blanche Hughes Children's Foundation.

\section{REFERENCES}

1. Vantourout P, Hayday A. Six-of-the-best: unique contributions of gammadelta T cells to immunology. Nat Rev Immunol (2013) 13(2):88-100. doi:10.1038/ nri3384

2. Kabelitz D. Gammadelta T-cells: cross-talk between innate and adaptive immunity. Cell Mol Life Sci (2011) 68(14):2331-3. doi:10.1007/s00018-011-0696-4

3. Hannani D, Ma Y, Yamazaki T, Dechanet-Merville J, Kroemer G, Zitvogel L. Harnessing gammadelta T cells in anticancer immunotherapy. Trends Immunol (2012) 33(5):199-206. doi:10.1016/j.it.2012.01.006

4. Xiang Z, Liu Y, Zheng J, Liu M, Lv A, Gao Y, et al. Targeted activation of human V $\gamma 9 \mathrm{~V} 82-\mathrm{T}$ cells controls Epstein-Barr virus-induced B Cell lymphoproliferative disease. Cancer Cell (2014) 26(4):565-76. doi:10.1016/j.ccr.2014.07.026

5. Smith-Garvin JE, Koretzky GA, Jordan MS. T cell activation. Annu Rev Immunol (2009) 27:591-619. doi:10.1146/annurev.immunol.021908.132706
6. Kalyan S, Kabelitz D. Defining the nature of human gammadelta T cells: a biographical sketch of the highly empathetic. Cell Mol Immunol (2013) 10(1):21-9. doi:10.1038/cmi.2012.44

7. Koretzky GA. Multiple roles of CD4 and CD8 in T cell activation. J Immunol (2010) 185(5):2643-4. doi:10.4049/jimmunol.1090076

8. Van Laethem F, Tikhonova AN, Singer A. MHC restriction is imposed on a diverse $\mathrm{T}$ cell receptor repertoire by CD4 and CD8 co-receptors during thymic selection. Trends Immunol (2012) 33(9):437-41. doi:10.1016/j.it.2012.05.006

9. Germain RN. T-cell development and the CD4-CD8 lineage decision. Nat Rev Immunol (2002) 2(5):309-22. doi:10.1038/nri798

10. Sato K, Ohtsuka K, Watanabe H, Asakura H, Abo T. Detailed characterization of gamma delta $\mathrm{T}$ cells within the organs in mice: classification into three groups. Immunology (1993) 80(3):380-7.

11. Kabelitz D, Kalyan S, Oberg HH, Wesch D. Human Vdelta2 versus nonVdelta2 gammadelta T cells in antitumor immunity. Oncoimmunology (2013) 2(3):e23304. doi:10.4161/onci.23304

12. Kabelitz D, Wesch D, He W. Perspectives of gammadelta T cells in tumor immunology. Cancer Res (2007) 67(1):5-8. doi:10.1158/0008-5472.CAN-063069

13. Lefranc MP. Nomenclature of the human $\mathrm{T}$ cell receptor genes. Curr Protoc Immunol (2001) Appendix 1:Appendix 1O. doi:10.1002/0471142735. ima0 10 s40

14. Xiong N, Raulet DH. Development and selection of gammadelta T cells. Immunol Rev (2007) 215:15-31. doi:10.1111/j.1600-065X.2006.00478.x

15. Hayday AC. Gammadelta T cells and the lymphoid stress-surveillance response. Immunity (2009) 31(2):184-96. doi:10.1016/j.immuni.2009.08.006

16. Hao J, Wu X, Xia S, Li Z, Wen T, Zhao N, et al. Current progress in gammadelta T-cell biology. Cell Mol Immunol (2010) 7(6):409-13. doi:10.1038/cmi.2010.50

17. Ishikawa $H$, Naito $T$, Iwanaga $T$, Takahashi-Iwanaga $H$, Suematsu M, Hibi $\mathrm{T}$, et al. Curriculum vitae of intestinal intraepithelial $\mathrm{T}$ cells: their developmental and behavioral characteristics. Immunol Rev (2007) 215:154-65. doi:10.1111/j.1600-065X.2006.00473.x

18. Carding SR, Egan PJ. Gammadelta T cells: functional plasticity and heterogeneity. Nat Rev Immunol (2002) 2(5):336-45. doi:10.1038/nri797

19. Bonneville M, O’Brien RL, Born WK. Gammadelta T cell effector functions: a blend of innate programming and acquired plasticity. Nat Rev Immunol (2010) 10(7):467-78. doi:10.1038/nri2781

20. Chodaczek G, Papanna V, Zal MA, Zal T. Body-barrier surveillance by epidermal gammadelta TCRs. Nat Immunol (2012) 13(3):272-82. doi:10.1038/ni. 2240

21. Xu B, Pizarro JC, Holmes MA, McBeth C, Groh V, Spies T, et al. Crystal structure of a gammadelta T-cell receptor specific for the human MHC class I homolog MICA. Proc Natl Acad Sci U S A (2011) 108(6):2414-9. doi:10.1073/pnas.1015433108

22. Li J, Cui L, He W. Distinct pattern of human Vdeltal gammadelta T cells recognizing MICA. Cell Mol Immunol (2005) 2(4):253-8.

23. Bauer S, Groh V, Wu J, Steinle A, Phillips JH, Lanier LL, et al. Activation of NK cells and T cells by NKG2D, a receptor for stress-inducible MICA. Science (1999) 285(5428):727-9. doi:10.1126/science.285.5428.727

24. Wrobel P, Shojaei H, Schittek B, Gieseler F, Wollenberg B, Kalthoff H, et al. Lysis of a broad range of epithelial tumour cells by human gamma delta $\mathrm{T}$ cells: involvement of NKG2D ligands and T-cell receptor- versus NKG2D-dependent recognition. Scand J Immunol (2007) 66(2-3):320-8. doi:10.1111/j.1365-3083. 2007.01963.x

25. Spada FM, Grant EP, Peters PJ, Sugita M, Melian A, Leslie DS, et al. Selfrecognition of CD1 by gamma/delta T cells: implications for innate immunity. J Exp Med (2000) 191(6):937-48. doi:10.1084/jem.191.6.937

26. Uldrich AP, Le Nours J, Pellicci DG, Gherardin NA, McPherson KG, Lim RT, et al. CD1d-lipid antigen recognition by the gammadelta TCR. Nat Immunol (2013) 14(11):1137-45. doi:10.1038/ni.2713

27. Paget C, Chow MT, Duret H, Mattarollo SR, Smyth MJ. Role of gammadelta $\mathrm{T}$ cells in alpha-galactosylceramide-mediated immunity. J Immunol (2012) 188(8):3928-39. doi:10.4049/jimmunol.1103582

28. Vermijlen D, Brouwer M, Donner C, Liesnard C, Tackoen M, Van Rysselberge $\mathrm{M}$, et al. Human cytomegalovirus elicits fetal gammadelta $\mathrm{T}$ cell responses in utero. J Exp Med (2010) 207(4):807-21. doi:10.1084/jem.20090348

29. Wesch D, Hinz T, Kabelitz D. Analysis of the TCR Vgamma repertoire in healthy donors and HIV-1-infected individuals. Int Immunol (1998) 10(8):1067-75. 
doi:10.1093/intimm/10.8.1067

30. Bukowski JF, Morita CT, Brenner MB. Human gamma delta T cells recognize alkylamines derived from microbes, edible plants, and tea: implications for innate immunity. Immunity (1999) 11(1):57-65. doi:10.1016/S1074-7613(00) 80081-3

31. Wang L, Kamath A, Das H, Li L, Bukowski JF. Antibacterial effect of human $\mathrm{V}$ gamma $2 \mathrm{~V}$ delta $2 \mathrm{~T}$ cells in vivo. J Clin Invest (2001) 108(9):1349-57. doi:10.1172/JCI13584

32. Munk ME, Elser C, Kaufmann SH. Human gamma/delta T-cell response to Listeria monocytogenes protein components in vitro. Immunology (1996) 87(2):230-5. doi:10.1046/j.1365-2567.1996.470549.x

33. Green AE, Lissina A, Hutchinson SL, Hewitt RE, Temple B, James D, et al. Recognition of nonpeptide antigens by human $\mathrm{V}$ gamma $9 \mathrm{~V}$ delta $2 \mathrm{~T}$ cells requires contact with cells of human origin. Clin Exp Immunol (2004) 136(3):472-82. doi:10.1111/j.1365-2249.2004.02472.x

34. Mookerjee-Basu J, Vantourout P, Martinez LO, Perret B, Collet X, Perigaud $\mathrm{C}$, et al. F1-adenosine triphosphatase displays properties characteristic of an antigen presentation molecule for Vgamma9Vdelta2 T cells. J Immunol (2010) 184(12):6920-8. doi:10.4049/jimmunol.0904024

35. Vantourout P, Mookerjee-Basu J, Rolland C, Pont F, Martin H, Davrinche $\mathrm{C}$, et al. Specific requirements for Vgamma9Vdelta2 $\mathrm{T}$ cell stimulation by a natural adenylated phosphoantigen. J Immunol (2009) 183(6):3848-57. doi:10.4049/jimmunol.0901085

36. Scotet E, Martinez LO, Grant E, Barbaras R, Jeno P, Guiraud M, et al. Tumor recognition following Vgamma9Vdelta2 $\mathrm{T}$ cell receptor interactions with a surface F1-ATPase-related structure and apolipoprotein A-I. Immunity (2005) 22(1):71-80. doi:10.1016/j.immuni.2004.11.012

37. Constant P, Davodeau F, Peyrat MA, Poquet Y, Puzo G, Bonneville M, et al. Stimulation of human gamma delta T cells by nonpeptidic mycobacterial ligands. Science (1994) 264(5156):267-70. doi:10.1126/science.8146660

38. Farnault L, Gertner-Dardenne J, Gondois-Rey F, Michel G, Chambost H, Hirsch I, et al. Clinical evidence implicating gamma-delta T cells in EBV control following cord blood transplantation. Bone Marrow Transplant (2013) 48(11):1478-9. doi:10.1038/bmt.2013.75

39. Hacker G, Kromer S, Falk M, Heeg K, Wagner H, Pfeffer K. V delta 1+ subset of human gamma delta $\mathrm{T}$ cells responds to ligands expressed by EBV-infected Burkitt lymphoma cells and transformed B lymphocytes. J Immunol (1992) 149(12):3984-9.

40. Knight A, Madrigal AJ, Grace S, Sivakumaran J, Kottaridis P, Mackinnon S, et al. The role of Vdelta2-negative gammadelta T cells during cytomegalovirus reactivation in recipients of allogeneic stem cell transplantation. Blood (2010) 116(12):2164-72. doi:10.1182/blood-2010-01-255166

41. Kabelitz D, Hinz T, Dobmeyer T, Mentzel U, Marx S, Bohme A, et al. Clonal expansion of Vgamma3/Vdelta3-expressing gammadelta $\mathrm{T}$ cells in an HIV-1/2-negative patient with CD4 T-cell deficiency. Br J Haematol (1997) 96(2):266-71. doi:10.1046/j.1365-2141.1997.d01-2027.x

42. Thompson K, Roelofs AJ, Jauhiainen M, Monkkonen H, Monkkonen J, Rogers MJ. Activation of gammadelta T cells by bisphosphonates. Adv Exp Med Biol (2010) 658:11-20. doi:10.1007/978-1-4419-1050-9_2

43. Nagamine I, Yamaguchi Y, Ohara M, Ikeda T, Okada M. Induction of gamma delta $\mathrm{T}$ cells using zoledronate plus interleukin-2 in patients with metastatic cancer. Hiroshima J Med Sci (2009) 58(1):37-44.

44. Chiplunkar S, Dhar S, Wesch D, Kabelitz D. gammadelta T cells in cancer immunotherapy: current status and future prospects. Immunotherapy (2009) 1(4):663-78. doi:10.2217/imt.09.27

45. D’Asaro M, La Mendola C, Di Liberto D, Orlando V, Todaro M, Spina $\mathrm{M}$, et al. $\mathrm{V}$ gamma $9 \mathrm{~V}$ delta $2 \mathrm{~T}$ lymphocytes efficiently recognize and kill zoledronate-sensitized, imatinib-sensitive, and imatinib-resistant chronic myelogenous leukemia cells. J Immunol (2010) 184(6):3260-8. doi:10.4049/ jimmunol.0903454

46. Thedrez A, Harly C, Morice A, Salot S, Bonneville M, Scotet E. IL-21-mediated potentiation of antitumor cytolytic and proinflammatory responses of human $\mathrm{V}$ gamma 9V delta $2 \mathrm{~T}$ cells for adoptive immunotherapy. J Immunol (2009) 182(6):3423-31. doi:10.4049/jimmunol.0803068

47. Chargui J, Combaret V, Scaglione V, Iacono I, Peri V, Valteau-Couanet D, et al. Bromohydrin pyrophosphate-stimulated Vgamma9delta2 $\mathrm{T}$ cells expanded ex vivo from patients with poor-prognosis neuroblastoma lyse autologous primary tumor cells. J Immunother (2010) 33(6):591-8. doi:10.1097/CJI. 0b013e3181dda207

48. Espinosa E, Belmant C, Pont F, Luciani B, Poupot R, Romagne F, et al. Chemical synthesis and biological activity of bromohydrin pyrophosphate, a potent stimulator of human gamma delta T cells. J Biol Chem (2001) 276(21):18337-44. doi:10.1074/jbc.M100495200

49. Fisher JP, Heuijerjans J, Yan M, Gustafsson K, Anderson J. gammadelta T cells for cancer immunotherapy: a systematic review of clinical trials. Oncoimmunology (2014) 3(1):e27572. doi:10.4161/onci.27572

50. Gomes AQ, Martins DS, Silva-Santos B. Targeting gammadelta T lymphocytes for cancer immunotherapy: from novel mechanistic insight to clinical application. Cancer Res (2010) 70(24):10024-7. doi:10.1158/0008-5472.CAN-103236

51. Wilhelm M, Kunzmann V, Eckstein S, Reimer P, Weissinger F, Ruediger T, et al. Gammadelta $\mathrm{T}$ cells for immune therapy of patients with lymphoid malignancies. Blood (2003) 102(1):200-6. doi:10.1182/blood-2002-12-3665

52. Kunzmann V, Smetak M, Kimmel B, Weigang-Koehler K, Goebeler M, Birkmann J, et al. Tumor-promoting versus tumor-antagonizing roles of gammadelta $\mathrm{T}$ cells in cancer immunotherapy: results from a prospective phase I/II trial. J Immunother (2012) 35(2):205-13. doi:10.1097/CJI.0b013e318245bble

53. Lang JM, Kaikobad MR, Wallace M, Staab MJ, Horvath DL, Wilding G, et al. Pilot trial of interleukin-2 and zoledronic acid to augment gammadelta $\mathrm{T}$ cells as treatment for patients with refractory renal cell carcinoma. Cancer Immunol Immunother (2011) 60(10):1447-60. doi:10.1007/s00262-011-1049-8

54. Dieli F, Vermijlen D, Fulfaro F, Caccamo N, Meraviglia S, Cicero G, et al. Targeting human \{gamma\}delta\} $\mathrm{T}$ cells with zoledronate and interleukin-2 for immunotherapy of hormone-refractory prostate cancer. Cancer Res (2007) 67(15):7450-7. doi:10.1158/0008-5472.CAN-07-0199

55. Meraviglia S, Eberl M, Vermijlen D, Todaro M, Buccheri S, Cicero G, et al. In vivo manipulation of Vgamma9Vdelta2 $\mathrm{T}$ cells with zoledronate and lowdose interleukin-2 for immunotherapy of advanced breast cancer patients. Clin Exp Immunol (2010) 161(2):290-7. doi:10.1111/j.1365-2249.2010.04167.x

56. Poccia F, Gioia C, Martini F, Sacchi A, Piacentini P, Tempestilli M, et al. Zoledronic acid and interleukin-2 treatment improves immunocompetence in HIV-infected persons by activating Vgamma9Vdelta2 T cells. AIDS (2009) 23(5):555-65. doi:10.1097/QAD.0b013e3283244619

57. Kobayashi H, Tanaka Y, Yagi J, Osaka Y, Nakazawa H, Uchiyama T, et al. Safety profile and anti-tumor effects of adoptive immunotherapy using gamma-delta T cells against advanced renal cell carcinoma: a pilot study. Cancer Immunol Immunother (2007) 56(4):469-76. doi:10.1007/s00262-006-0199-6

58. Bennouna J, Bompas E, Neidhardt EM, Rolland F, Philip I, Galea C, et al. Phase-I study of Innacell gammadelta, an autologous cell-therapy product highly enriched in gamma9delta2 T lymphocytes, in combination with IL-2, in patients with metastatic renal cell carcinoma. Cancer Immunol Immunother (2008) 57(11):1599-609. doi:10.1007/s00262-008-0491-8

59. Bennouna J, Levy V, Sicard H, Senellart H, Audrain M, Hiret S, et al. Phase I study of bromohydrin pyrophosphate (BrHPP, IPH 1101), a Vgamma9Vdelta2 $\mathrm{T}$ lymphocyte agonist in patients with solid tumors. Cancer Immunol Immunother (2010) 59(10):1521-30. doi:10.1007/s00262-010-0879-0

60. Nakajima J, Murakawa T, Fukami T, Goto S, Kaneko T, Yoshida Y, et al. A phase I study of adoptive immunotherapy for recurrent non-small-cell lung cancer patients with autologous gammadelta T cells. Eur J Cardiothorac Surg (2010) 37(5):1191-7. doi:10.1016/j.ejcts.2009.11.051

61. Sakamoto M, Nakajima J, Murakawa T, Fukami T, Yoshida Y, Murayama T, et al. Adoptive immunotherapy for advanced non-small cell lung cancer using zoledronate-expanded gammadeltaTcells: a phase I clinical study. J Immunother (2011) 34(2):202-11. doi:10.1097/CJI.0b013e318207ecfb

62. Izumi T, Kondo M, Takahashi T, Fujieda N, Kondo A, Tamura N, et al. Ex vivo characterization of gammadelta $\mathrm{T}$-cell repertoire in patients after adoptive transfer of Vgamma9Vdelta2 T cells expressing the interleukin-2 receptor beta-chain and the common gamma-chain. Cytotherapy (2013) 15(4):481-91. doi:10.1016/j.jcyt.2012.12.004

63. Abe Y, Muto M, Nieda M, Nakagawa Y, Nicol A, Kaneko T, et al. Clinical and immunological evaluation of zoledronate-activated Vgamma9gammadelta Tcell-based immunotherapy for patients with multiple myeloma. Exp Hematol (2009) 37(8):956-68. doi:10.1016/j.exphem.2009.04.008

64. Kobayashi H, Tanaka Y, Yagi J, Minato N, Tanabe K. Phase I/II study of adoptive transfer of gammadelta T cells in combination with zoledronic acid and IL-2 to patients with advanced renal cell carcinoma. Cancer Immunol Immunother 
(2011) 60(8):1075-84. doi:10.1007/s00262-011-1021-7

65. Nicol AJ, Tokuyama H, Mattarollo SR, Hagi T, Suzuki K, Yokokawa K, et al. Clinical evaluation of autologous gamma delta T cell-based immunotherapy for metastatic solid tumours. Br J Cancer (2011) 105(6):778-86. doi:10.1038/ bjc. 2011.293

66. Godder KT, Henslee-Downey PJ, Mehta J, Park BS, Chiang KY, Abhyankar S, et al. Long term disease-free survival in acute leukemia patients recovering with increased gammadelta $\mathrm{T}$ cells after partially mismatched related donor bone marrow transplantation. Bone Marrow Transplant (2007) 39(12):751-7. doi:10.1038/sj.bmt.1705650

67. Lamb LS Jr, Gee AP, Hazlett LJ, Musk P, Parrish RS, O’Hanlon TP, et al. Influence of $\mathrm{T}$ cell depletion method on circulating gammadelta $\mathrm{T}$ cell reconstitution and potential role in the graft-versus-leukemia effect. Cytotherapy (1999) 1(1):7-19. doi:10.1080/0032472031000141295

68. Lamb LS Jr, Henslee-Downey PJ, Parrish RS, Godder K, Thompson J, Lee $\mathrm{C}$, et al. Increased frequency of TCR gamma delta $+\mathrm{T}$ cells in diseasefree survivors following $\mathrm{T}$ cell-depleted, partially mismatched, related donor bone marrow transplantation for leukemia. J Hematother (1996) 5(5):503-9. doi:10.1089/scd.1.1996.5.503

69. Lamb LS Jr, Musk P, Ye Z, van Rhee F, Geier SS, Tong JJ, et al. Human gammadelta(+) T lymphocytes have in vitro graft vs leukemia activity in the absence of an allogeneic response. Bone Marrow Transplant (2001) 27(6):601-6. doi:10.1038/sj.bmt.1702830

70. Scheper W, van Dorp S, Kersting S, Pietersma F, Lindemans C, Hol S, et al. gammadeltaT cells elicited by CMV reactivation after allo-SCT crossrecognize CMV and leukemia. Leukemia (2013) 27(6):1328-38. doi:10.1038/ leu.2012.374

71. Wilhelm M, Smetak M, Schaefer-Eckart K, Kimmel B, Birkmann J, Einsele $\mathrm{H}$, et al. Successful adoptive transfer and in vivo expansion of haploidentical gammadelta T cells. J Transl Med (2014) 12:45. doi:10.1186/1479-5876-12-45

72. Qi J, Zhang J, Zhang S, Cui L, He W. Immobilized MICA could expand human Vdeltal gammadelta $\mathrm{T}$ cells in vitro that displayed major histocompatibility complex class I chain-related A-dependent cytotoxicity to human epithelial carcinomas. Scand J Immunol (2003) 58(2):211-20. doi:10.1046/j.1365-3083. 2003.01288.x

73. Kang N, Zhou J, Zhang T, Wang L, Lu F, Cui Y, et al. Adoptive immunotherapy of lung cancer with immobilized anti-TCRgammadelta antibody-expanded human gammadelta T-cells in peripheral blood. Cancer Biol Ther (2009) 8(16):1540-9. doi:10.4161/cbt.8.16.8950

74. Zhou J, Kang N, Cui L, Ba D, He W. Anti-gammadelta TCR antibody-expanded gammadelta T cells: a better choice for the adoptive immunotherapy of lymphoid malignancies. Cell Mol Immunol (2012) 9(1):34-44. doi:10.1038/cmi. 2011.16

75. Dokouhaki P, Han M, Joe B, Li M, Johnston MR, Tsao MS, et al. Adoptive immunotherapy of cancer using ex vivo expanded human gammadelta T cells: a new approach. Cancer Lett (2010) 297(1):126-36. doi:10.1016/j.canlet.2010. 05.005

76. Lopez RD, Xu S, Guo B, Negrin RS, Waller EK. CD2-mediated IL-12-dependent signals render human gamma delta-T cells resistant to mitogen-induced apoptosis, permitting the large-scale ex vivo expansion of functionally distinct lymphocytes: implications for the development of adoptive immunotherapy strategies. Blood (2000) 96(12):3827-37.

77. Deniger DC, Maiti S, Mi T, Switzer K, Ramachandran V, Hurton LV, et al. Activating and propagating polyclonal gamma delta $\mathrm{T}$ cells with broad specificity for malignancies. Clin Cancer Res (2014) 20(22):5708-19. doi:10.1158/10780432.CCR-13-3451

78. Deniger DC, Switzer K, Mi T, Maiti S, Hurton L, Singh H, et al. Bispecific Tcells expressing polyclonal repertoire of endogenous gammadelta T-cell receptors and introduced CD19-specific chimeric antigen receptor. Mol Ther (2013) 21(3):638-47. doi:10.1038/mt.2012.267

79. Fisher J, Yan M, Heuijerjans J, Carter L, Abolhassani A, Frosch J, et al. Neuroblastoma killing properties of $\mathrm{V}-\delta 2$ and $\mathrm{V}-\delta 2$ negative gamma delta $\mathrm{T}$ cells following expansion by artificial antigen presenting cells. Clin Cancer Res (2014) 20(22):5720-32. doi:10.1158/1078-0432.CCR-13-3464

80. Dechanet-Merville J. Promising cell-based immunotherapy using gamma delta T cells: together is better. Clin Cancer Res (2014) 20(22):5573-5. doi:10.1158/ 1078-0432.CCR-14-1371
81. O'Connor CM, Sheppard S, Hartline CA, Huls H, Johnson M, Palla SL, et al. Adoptive T-cell therapy improves treatment of canine non-Hodgkin lymphoma post chemotherapy. Sci Rep (2012) 2:249. doi:10.1038/srep00249

82. Singh H, Figliola MJ, Dawson MJ, Olivares S, Zhang L, Yang G, et al. Manufacture of clinical-grade CD19-specific $\mathrm{T}$ cells stably expressing chimeric antigen receptor using sleeping beauty system and artificial antigen presenting cells. PLoS One (2013) 8(5):e64138. doi:10.1371/journal.pone. 0064138

83. Huls MH, Figliola MJ, Dawson MJ, Olivares S, Kebriaei P, Shpall EJ, et al. Clinical application of sleeping beauty and artificial antigen presenting cells to genetically modify T cells from peripheral and umbilical cord blood. $J$ Vis Exp (2013) 72:e50070. doi:10.3791/50070

84. Rushworth D, Jena B, Olivares S, Maiti S, Briggs N, Somanchi S, et al. Universal artificial antigen presenting cells to selectively propagate $\mathrm{T}$ cells expressing chimeric antigen receptor independent of specificity. J Immunother (2014) 37(4):204-13. doi:10.1097/CJI.0000000000000032

85. Caccamo N, La Mendola C, Orlando V, Meraviglia S, Todaro M, Stassi G, et al. Differentiation, phenotype, and function of interleukin-17-producing human Vgamma9Vdelta2 T cells. Blood (2011) 118(1):129-38. doi:10.1182/ blood-2011-01-331298

86. DeBarros A, Chaves-Ferreira M, d'Orey F, Ribot JC, Silva-Santos B. CD70CD27 interactions provide survival and proliferative signals that regulate $\mathrm{T}$ cell receptor-driven activation of human gammadelta peripheral blood lymphocytes. Eur J Immunol (2011) 41(1):195-201. doi:10.1002/eji.201040905

87. Ribot JC, deBarros A, Pang DJ, Neves JF, Peperzak V, Roberts SJ, et al. CD27 is a thymic determinant of the balance between interferon-gamma- and interleukin 17-producing gammadelta T cell subsets. Nat Immunol (2009) 10(4):427-36. doi:10.1038/ni.1717

88. Heemskerk MH. T-cell receptor gene transfer for the treatment of leukemia and other tumors. Haematologica (2010) 95(1):15-9. doi:10.3324/haematol. 2009.016022

89. van der Veken LT, Coccoris M, Swart E, Falkenburg JH, Schumacher TN, Heemskerk MH. Alpha beta T cell receptor transfer to gamma delta T cells generates functional effector cells without mixed TCR dimers in vivo. J Immunol (2009) 182(1):164-70. doi:10.4049/jimmunol.182.1.164

90. Hiasa A, Nishikawa H, Hirayama M, Kitano S, Okamoto S, Chono H, et al. Rapid alphabeta TCR-mediated responses in gammadelta $\mathrm{T}$ cells transduced with cancer-specific TCR genes. Gene Ther (2009) 16(5):620-8. doi:10.1038/ gt.2009.6

91. Murayama M, Tanaka Y, Yagi J, Uchiyama T, Ogawa K. Antitumor activity and some immunological properties of gammadelta T-cells from patients with gastrointestinal carcinomas. Anticancer Res (2008) 28(5B):2921-31.

92. van der Veken LT, Hagedoorn RS, van Loenen MM, Willemze R, Falkenburg JH, Heemskerk MH. Alphabeta T-cell receptor engineered gammadelta T cells mediate effective antileukemic reactivity. Cancer Res (2006) 66(6):3331-7. doi:10.1158/0008-5472.CAN-05-4190

93. Marcu-Malina V, Heijhuurs S, van Buuren M, Hartkamp L, Strand S, Sebestyen $\mathrm{Z}$, et al. Redirecting alphabeta $\mathrm{T}$ cells against cancer cells by transfer of a broadly tumor-reactive gammadeltaT-cell receptor. Blood (2011) 118(1):50-9. doi:10.1182/blood-2010-12-325993

94. Lamb LS Jr, Bowersock J, Dasgupta A, Gillespie GY, Su Y, Johnson A, et al. Engineered drug resistant gammadelta $\mathrm{T}$ cells kill glioblastoma cell lines during a chemotherapy challenge: a strategy for combining chemo- and immunotherapy. PLoS One (2013) 8(1):e51805. doi:10.1371/journal.pone.0051805

95. June CH. Principles of adoptive T cell cancer therapy. J Clin Invest (2007) 117(5):1204-12. doi:10.1172/JCI32446

96. Singh H, Huls H, Kebriaei P, Cooper LJ. A new approach to gene therapy using sleeping beauty to genetically modify clinical-grade T cells to target CD19. Immunol Rev (2014) 257(1):181-90. doi:10.1111/imr.12137

97. Jena B, Dotti G, Cooper LJ. Redirecting T-cell specificity by introducing a tumor-specific chimeric antigen receptor. Blood (2010) 116(7):1035-44. doi:10.1182/blood-2010-01-043737

98. Rischer M, Pscherer S, Duwe S, Vormoor J, Jurgens H, Rossig C. Human gammadelta $\mathrm{T}$ cells as mediators of chimeric-receptor redirected anti-tumour immunity. Br J Haematol (2004) 126(4):583-92. doi:10.1111/j.1365-2141. 2004.05077.x 
99. Hackett PB Jr, Aronovich EL, Hunter D, Urness M, Bell JB, Kass SJ, et al. Efficacy and safety of sleeping beauty transposon-mediated gene transfer in preclinical animal studies. Curr Gene Ther (2011) 11(5):341-9. doi:10.2174/ 156652311797415827

100. Hackett PB, Largaespada DA, Cooper LJ. A transposon and transposase system for human application. Mol Ther (2010) 18(4):674-83. doi:10.1038/ mt.2010.2

101. Hackett PB, Largaespada DA, Switzer KC, Cooper LJ. Evaluating risks of insertional mutagenesis by DNA transposons in gene therapy. Transl Res (2013) 161(4):265-83. doi:10.1016/j.trsl.2012.12.005

102. Maiti SN, Huls H, Singh H, Dawson M, Figliola M, Olivares S, et al. Sleeping beauty system to redirect T-cell specificity for human applications. $J$ Immunother (2013) 36(2):112-23. doi:10.1097/CJI.0b013e3182811ce9

103. Wadman SA, Clark KJ, Hackett PB. Fishing for answers with transposons. Mar Biotechnol (NY) (2005) 7(3):135-41. doi:10.1007/s10126-004-0068-2

104. Liu G, Aronovich EL, Cui Z, Whitley CB, Hackett PB. Excision of sleeping beauty transposons: parameters and applications to gene therapy. J Gene Med (2004) 6(5):574-83. doi:10.1002/jgm.486

105. Liu G, Geurts AM, Yae K, Srinivasan AR, Fahrenkrug SC, Largaespada DA, et al. Target-site preferences of sleeping beauty transposons. J Mol Biol (2005) 346(1):161-73. doi:10.1016/j.jmb.2004.09.086

106. Singh H, Manuri PR, Olivares S, Dara N, Dawson MJ, Huls H, et al. Redirecting specificity of T-cell populations for CD19 using the sleeping beauty system. Cancer Res (2008) 68(8):2961-71. doi:10.1158/0008-5472.CAN-075600

107. Tran E, Rosenberg SA. T-cell therapy against cancer mutations. Oncotarget (2014) 5(13):4579-80.

108. Tran E, Turcotte S, Gros A, Robbins PF, Lu YC, Dudley ME, et al. Cancer immunotherapy based on mutation-specific CD4+ $\mathrm{T}$ cells in a patient with epithelial cancer. Science (2014) 344(6184):641-5. doi:10.1126/science. 1251102

109. Robbins PF, Lu YC, El-Gamil M, Li YF, Gross C, Gartner J, et al. Mining exomic sequencing data to identify mutated antigens recognized by adoptively transferred tumor-reactive T cells. Nat Med (2013) 19(6):747-52. doi:10.1038/nm.3161

110. Peng G, Wang HY, Peng W, Kiniwa Y, Seo KH, Wang RF. Tumor-infiltrating gammadelta $\mathrm{T}$ cells suppress $\mathrm{T}$ and dendritic cell function via mechanisms controlled by a unique toll-like receptor signaling pathway. Immunity (2007) 27(2):334-48. doi:10.1016/j.immuni.2007.05.020

111. Raspollini MR, Castiglione F, Rossi Degl'innocenti D, Amunni G, Villanucci A, Garbini F, et al. Tumour-infiltrating gamma/delta T-lymphocytes are correlated with a brief disease-free interval in advanced ovarian serous carcinoma. Ann Oncol (2005) 16(4):590-6. doi:10.1093/annonc/mdi112

112. Forget MA, Malu S, Liu H, Toth C, Maiti S, Kale C, et al. Activation and propagation of tumor-infiltrating lymphocytes on clinical-grade designer artificial antigen-presenting cells for adoptive immunotherapy of melanoma. $J$ Immunother (2014) 37(9):448-60. doi:10.1097/CJI.0000000000000056

113. Anderson J, Gustafsson K, Himoudi N. Licensing of killer dendritic cells in mouse and humans: functional similarities between IKDC and human blood gammadelta T-lymphocytes. J Immunotoxicol (2012) 9(3):259-66. doi: 10.3109/1547691X.2012.685528

114. Himoudi N, Morgenstern DA, Yan M, Vernay B, Saraiva L, Wu Y, et al. Human gammadelta $\mathrm{T}$ lymphocytes are licensed for professional antigen presentation by interaction with opsonized target cells. J Immunol (2012) 188(4):1708-16. doi:10.4049/jimmunol.1102654

115. Anderson J, Gustafsson K, Himoudi N, Yan M, Heuijerjans J. Licensing of gammadeltaT cells for professional antigen presentation: a new role for antibodies in regulation of antitumor immune responses. Oncoimmunology (2012) 1(9):1652-4. doi:10.4161/onci.21971

116. Kang N, Tang L, Li X, Wu D, Li W, Chen X, et al. Identification and characterization of Foxp3(+) gammadelta T cells in mouse and human. Immunol Lett (2009) 125(2):105-13. doi:10.1016/j.imlet.2009.06.005

Conflict of Interest Statement: Dr. Cooper founded and owns InCellerate, Inc. He has patents with Sangamo BioSciences with artificial nucleases. He consults with Targazyme, Inc. (formerly American Stem cells, Inc.), GE Healthcare, Ferring Pharmaceuticals, Inc., and Bristol-Myers Squibb. He receives honoraria from Miltenyi Biotec. Other authors declare no other competing financial interests.

Received: 29 September 2014; accepted: 28 November 2014; published online: 11 December 2014

Citation: Deniger DC, Moyes JS and Cooper LJN (2014) Clinical applications of gamma delta $T$ cells with multivalent immunity. Front. Immunol. 5:636. doi: 10.3389/fimmu.2014.00636

This article was submitted to T Cell Biology, a section of the journal Frontiers in Immunology.

Copyright (C) 2014 Deniger, Moyes and Cooper. This is an open-access article distributed under the terms of the Creative Commons Attribution License (CC BY). The use, distribution or reproduction in other forums is permitted, provided the original author(s) or licensor are credited and that the original publication in this journal is cited, in accordance with accepted academic practice. No use, distribution or reproduction is permitted which does not comply with these terms. 